\title{
Research on the Impact of Multi-source Intellectual Capital Information Disclosure on Corporate Value in the Big Data Environment-Based on Mediating Effect of Investor's Confidence
}

\author{
Wang fu-sheng,Yuan bei, Guo cai-cai \\ School of Management, Harbin Institute of Technology, P.R.China, 150001
}

\begin{abstract}
In recent years, Internet technology has been developing continuously. Compared with the disclosure of intellectual capital in the traditional environment, the disclosure in big data environment has become diversified from content to form. As the provision and dissemination of capital market information is more timeliness, the means which the public access to information are becoming increasingly varied. Based on the theory of investor sentiment, this paper analyzes the relationship between multi-source intellectual capital information disclosure, investor confidence and corporate value. This paper selects the data of GEM listed companies in China from 2013 to 2015, and uses the regression analysis method to carry on the empirical test. The results show that there is a significant positive correlation between multi-source intellectual capital information disclosure and corporate value, and investor confidence plays a mediating role in the relationship between the intellectual capital information disclosure and the corporate value.
\end{abstract}

Key words-intellectual capital; information disclosure; investor's confidence

\section{Introduction}

With the advent of the big data era, the public can obtain a lot of resources to reveal more information about the intellectual capital. In the big data environment, the intellectual capital information disclosed by the listed company will be closer to the intellectual capital itself. The sources for reporting intellectual capital are also richer and more diverse. The Internet is considered to be a better medium for the disclosure of intellectual capital. The emergence of new media, such as corporate website, microblog and wechat, has become important carriers of intellectual capital information disclosure. It can provide more detailed dynamic information to the existing and potential investors. The importance of intellectual capital information disclosure is prominent, and intellectual capital information disclosure can promote the rapid development of enterprises. Therefore, in order to meet the reasonable needs of enterprise investors to assess the value of enterprises, listed companies disclose intellectual capital information through a variety of channels. China Securities Regulatory Commission stipulates in 2007: "All companies should disclose non-financial information about the future development of the company in the discussion and analysis of the financial reporting management" ( $\mathrm{Hu}$, et al., 2013). In accordance with the requirements of the commission, the listed companies disclose some of the intellectual capital information in the annual report, prospectus and other mandatory disclosure reports. It can be seen that intellectual capital information disclosure has changed from traditional mandatory disclosure report to multi-source information disclosure. However, there are a lot of researches on the relationship between intellectual capital information disclosure and corporate value in the mandatory disclosure report, and there is little research on the relationship between information disclosure and corporate value under the multisource approach of intellectual capital. In addition, the value of the enterprise shows that the investor's assessment of the future value creation capability of the enterprise is "exposed". The path of the intellectual capital information disclosure to the corporate value is "hidden". As the recipient of information disclosure, the investors' behavior can effect on the value of the enterprise. High-quality information disclosure can reduce the asymmetry of information in the securities market, reduce the transaction costs of investors in decision-making, and improve investor confidence, while the behavior of the changes will lead to fluctuations in stock prices. However, few scholars have introduced investor confidence to explain the relationship between intellectual capital information disclosure and the corporate value. In view of the shortcomings of existing research, this paper attempts to consider the direct disclosure of intellectual capital information and corporate value through the perspective of investor. Can the multi-source information disclosure of the intellectual capital affect investor confidence? Further more, if it can affect investor confidence, then the diversification of intellectual capital information disclosure can have some relationships with the corporate value?

The paper has the following structure. Section 2 introduces the background related to intellectual capital disclosure research and a review of recent Big Data trends. Section 3 presents the hypotheses of the research. Section 4 is the empirical analysis and the experimental results are analyzed in section 5. Section 6 discusses the authors'conclusions. 


\section{Literature review}

\section{A. Intellectual Capital Information Disclosure and Corporate Value}

The disclosure of intellectual capital information belongs to the enterprise voluntary information disclosure, which is one of the important mechanisms of transmitting information. Based on the theory of signal transmission, intellectual capital information is very important to the internal information. Disclosure of high-quality intellectual capital information can alleviate the information asymmetry between the company and the external investors effectively. The disclosure of intellectual capital will be able to convey good signal to the market, enhance investor expectations of the enterprise, and avoid adverse selection. At the same time, based on the theory of information asymmetry, Watts (2003) finds that enterprises with high-quality accounting information will reduce the company's future risks and the financing costs, which can also enhance corporate value. Biddle and Hilary et al. (2014) have conducted empirical research on the relationship between accounting information quality and investment efficiency. They find that high-quality accounting information can help reduce the cost of information, alleviate the problem of insufficient investment and enhance the corporate value. Some scholars have shown that the disclosure of intellectual capital information can help to improve the quality of enterprise accounting information and realize the maximization of corporate value. Indra Abeysekara (2011) has studied the relationship between corporate intelligence capital information disclosure and corporate value in different political systems. Mohammad J Abdolm ohammadi (2005) has selected 60 companies from Fortune 500 companies as samples and obtain intellectual capital information from these companies' annual reports of 1993-1997 to verify the degree of intellectual capital disclosure. There is a positive impact. R Orens et al (2009) extracts intellectual capital information samples from 267 companies in four European countries, and finds that there is a positive correlation between intellectual capital information disclosure and corporate value. Jiang Yanhui (2014) investigates the relationship between the information disclosures of the intellectual capital of the high-tech enterprises of the main board. It is found that the level of Internet information disclosure of listed companies is higher; the value of the enterprise is greater. Xiao Huafang and Wan Wenzhong (2009) argue that intellectual capital information is an important driver of enterprises. The disclosure of intellectual capital information can not only convey the company's business strategy to the outside world, but also reduce the information asymmetry. Ran Qiuhong et al. (2007) analyzes the content of non-monetary measured intellectual capital information disclosed by 223 listed companies in 2005 , and estimates the intellectual capital information measured by money. The empirical results show that the intellectual capital has produced the organizational performance positively. The intellectual capital information measured in money has a significant relevance to the corporate value, and the value relevance of the intellectual capital information of monetary measurement has not been clearly manifested.

\section{B. Intellectual Capital Information Disclosure and Investor Confidence}

Information disclosure is an important link between enterprises and investors, enterprises are the supply side of information and the demand side of funds, and investors are the demand side of information and the supply side of funds. The quality of information disclosure has always been highly concerned by all kinds of investors. Based on the theory of investor behavior, investors are always seeking to maximize their own interests. The investors can choose the optimal behavior in the given environment program and can always respond to market information. Behavioral finance argues that when investors invest in decision-making, they collect information about the company and seek support for investment behavior. Therefore, for investors, the quality of intellectual capital information disclosure affects the level of its investment risk level. The low-quality intellectual capital information disclosure means high uncertainty in the future, and the risk of investors will have influence on investors' confidence, which can finally affect the investment behavior of investors. At present, although there is little research on the influence of the quality of intellectual capital information disclosure on investors' confidence, Huang Zhongsheng and Dong Birong (2015) think that information disclosure is the main channel for enterprises to communicate with investors. It can narrow the information gap between the investors and enhance the investor's confidence. The study by Wiliam R • scott (2001) shows that voluntary information disclosure helps information users assess the company's future profitability. Lei Guangyong (2012) improved its estimation of investor confidence index, using the main business income growth rate, institutional investors' shareholding ratio and book value. The results proved the corporate governance information disclosure quality and investment owns positive correlation. Meng Hao (2014) constructs the empirical test of the micro investor confidence index of each listed company, proving that the improvement of enterprise information disclosure level can reduce the cost of equity capital through investor confidence. The quality of accounting information is improved, and the effect of investor confidence is more obvious. Liao Qian (2014) shows that the positive impact of the quality of accounting information on investor confidence in listed companies can persuade the listed companies to take the initiative to improve the quality of accounting information and help to build a virtuous circle of accounting information and confidence. Through the study of the above scholars, we can see that as an important part of corporate internal control information disclosure, intellectual capital information disclosure will have an impact on investor confidence.

\section{Investor Confidence and Corporate Value}

According to investor sentiment theory, capital market and investor behavior will be affected by investor sentiment to a certain extent. The value of listed companies is related to the value of the stock, which shows that corporate value and investor confidence should also be some kind of link. Delong et al. (1990) constructs the basic theoretical model of noise trading, which proves the equilibrium price of the stock can be influenced by investor sentiment. Barberis et al. (1998), Hong 
\& steinle (1999) study the impact of investor specific psychological mood bias on stock prices in the decisionmaking process. Brown \& Clif (2005) finds that there is a significant correlation between investor sentiment and stock returns over the same period. Wang Meixian and Sun Jianjun et al. (2004) select the data in Shanghai and Shenzhen Stock Markets, and the results show that investor sentiment will bring some impact to the stock price. They find that changes in institutional investor sentiment affect the stock market gains and the risk premium significantly. Wu Yiran et al. (2007) argue that investor sentiment is an important factor in asset pricing. Lei Guangyong et al. (2012) have experimentally examined the positive correlation between investor confidence and stock returns. Based on the theory of investor sentiment, Deng Xidong et al. (2016) chooses the listed companies of China's A-share high-tech enterprises from 2011 to 2013 as the sample, and puts forward the investment index of intellectual capital information disclosure, investor confidence and corporate value of listed companies in high-tech enterprises. The results show that investor confidence indirectly affects the value of high-tech enterprises.

Therefore, what is the intellectual capital information disclosure on the role of corporate value mechanism? It can be seen that the research on intellectual capital information disclosure is still at the initial stage, which need to be developed and perfected further.

\section{RESEARCH HYPOTHESES}

Baron and Kenny point out that an intermediary variable has to meet the following conditions: First, the intermediary variables and explanatory variables have a strong relationship. Second, the intermediary variables and explained variables have a strong relationship. Based on the above analysis, there is a close relationship between intellectual capital information disclosure, investor confidence and corporate value. As a strategic resource of enterprises, intellectual capital constitutes the basis for enterprises to maintain sustainable competitive advantage. These strategic resources are fully disclosed through corporate reporting, which can improve the relevance, adequacy and timeliness of accounting information. Thereby, investors can make more efficient decisions, and thus promote the improvement of corporate performance. The lack of intellectual capital information disclosure will not only increase the investment cost of investors, but also lead to the lack of capitalization of intellectual capital-intensive enterprises. Therefore, the intellectual capital has become the key driving force of corporate value and competitive advantage. The intellectual capital information has gradually become the core information of the enterprises which is concerned with the stakeholders. The investors make business expectations and evaluation through the enterprise intellectual capital information disclosure. When investors are hit by confidence, they will sell a large number of stocks, and the stock fell to the bottom, corporate value can not be a reasonable reflection. High-quality information disclosure can enhance the confidence of investors, and it can be reflected in the stock price, which can be ultimately affecting the overall value of the enterprise fluctuations. In the impact of intellectual capital information disclosure on corporate value, investor confidence has a mediating effect. In this paper, we propose the following hypotheses:

H1: There is a significant positive correlation between the information disclosure of intellectual capital and the future value of the enterprise.

$\mathrm{H} 2$ : The multi-source information disclosure of intellectual capital has a significantly positive influence on the investor confidence.

H3: The investor confidence is positively related to the future value of the firm.

\section{EMPIRICAL RESEARCH}

\section{A. Samples and data sources}

China Securities Regulatory Commission Bulletin [2010] No. 8 "Guidelines on Doing a Good Job further in the Growth Enterprise Market" (hereinafter referred to as the announcement) requires that the listed companies from GEM must conform to the development direction of the national strategic emerging industries and clearly defined the operation areas, mainly including: new energy, new materials, information, biological and new medicine, energy saving and environmental protection, aerospace, marine, advanced manufacturing, high-tech services and other enterprises from other areas with the independent innovation ability and strong growth. These companies pay more attention to the innovation and growth, and most companies have their own key core technology, research and innovation advantages and strong market development capabilities. In these emerging industries, the importance of intellectual capital is more prominent. GEM listed companies will pay more attention to the intellectual capital information disclosure. Therefore, this paper selected GEM listed companies which are listed for three consecutive years from 2013 to 2015as the object of study, the sample company is determined from the GEM listed companies directory according to the Shenzhen Stock Exchange website.

We collect the relevant information not only from the disclosure of the annual report of the listed companies, but also from the information which is published by the listed companies' websites. At the same time, the collection of microblogging data is collected from Sina microblogging. Taking into account the official and authoritative of the information collection, we collect the companies which contains the name of the listed company or the simply name, and the users with authentication $\mathrm{v}$ that passed the Sina microblogging authentic identity.

On this basis, we also screened the original data as follows: delete microblogging without any information; delete microblogging information (such as the heart chicken soup and weather conditions) which is completely unrelated to the company's business activities and the microblogging information of the company's marketing purposes (such as companies do the promotional activities, prizes and other content). The financial data and the incomplete sample of listed companies are excluded, we get 174 research samples by using three years of data. The data of the listed companies are collected from the website of China Securities Regulatory 
Commission, Shenzhen Stock Exchange website, CSMAR database, Juchao information network, the annual report of the listed companies and western securities great wisdom website. Data is collected by using database query, network data collection, manual reading and other methods. In addition, excel and stata14 is used for data statistics and regression analysis.

\section{B. Variable description}

\section{Independent Variable: Corporate value}

The explanatory variables of this paper are corporate value (VALUE). As the financial indicators of the firm may have strong correlation, the corporate value is more accurate by using the Tobin $\mathrm{Q}$ index. Tobin $\mathrm{Q}$ is equal to the ratio of enterprise capital market value and asset replacement cost, which is one of the important indexes to measure the corporate value. Tobin $\mathrm{Q}$ which is used in this paper is based on its standard calculation formula, and we use Wande and Cathay Pacific Database to collect corporate market value, the end of the total asset value and other related data, the data is calculated after the excluding the abnormal ones.

Dependent Variable: Capital information disclosure by the multi-source

At present, there isn't a unified intellectual capital information measurement standard in China. However, in the existing research, the measurement method of intellectual capital information disclosure can be divided into two kinds: content analysis and index method.

Most of the existing literatures are based on content analysis (Beattie and Thomson, 2007; Guthrie and Abeysekera, 2006; Zhang, 2008, Ran, 2007). Content analysis is mainly through the content analysis of annual report and classification, and find out its characteristics and make quantitative analysis.

Because the intellectual capital information is mostly in the form of words and graphs in the annual report, this method can discern and compare the intellectual capital information disclosure in different companies, the choice of analysis unit is involved; therefore, it has been criticized in recent years. And the index measurement method is relatively accurate (Jiang, 2014; Chu, 2011). To be specific, first, the information disclosure of intellectual capital is divided into large categories, and then refines the class into small categories, and makes the quantitative description and qualitative description by assigning each sub-category, and finally summarizes the scores of the different sub-categories. As the intellectual capital information is a multi-source in this paper, the intellectual capital information which is disclosed by the listed company's annual report is analyzed and summed up by the content analysis method. The result is absolute value and cannot be directly measured .Therefore, in order to overcome this shortcoming, this paper constructs the Intellectual Capital Information Disclosure Index (ICIDI) of listed companies on the basis of the statistics and sum up of intellectual capital information by the means of content analysis in the framework. According to the detail degree of information, the specific approach is as follows:
This paper also draws on the existing research practice, according to the intellectual capital classification framework of Guthrie (2000) which is widely cited and today's academic circles on the composition of intellectual capital and its specific content (Chen, 2011; Zhang, 2013; Jiang, 2014). At the same time, since this study of intellectual capital information is extracted from various channels, the author refer to the information disclosure of new media in the network of listed companies (He, 2016; Jiang, 2014; Wang, 2013) when constructing the framework of intellectual capital information disclosure index, the framework of the intellectual capital information is determined as the human capital, organization (structured) capital, and relationship(consumer) capital three parts, 40 elements in total, the multi-source intellectual capital information disclosure framework as the table 1 shows:

Tab. 1: Content Framework of the Multi-channel Intellectual Capital Information Disclosure

Classification of Intellectual capital information disclosure

Content

Staff education background, staff recruitment information, education and training, innovation ability, professional

Human Capital (11 items) staff ratio, professional and technical ability, staff salaries and benefits, employee satisfaction and identity, staff turnover rate, high-end talent ratio, manager management level

Organizational structure, business process, technological innovation, corporate culture, management philosophy, business Structured Capital (13 items) philosophy, environmental protection, intellectual property and core technology, trade secrets, R \& D investment, company operating efficiency, information network system, management process

Corporate reputation, brand prestige and trademark awareness, social responsibility, investor relations, business partners strategic alliance, influential companies or contracts, business channels, market share, marketing strategy, customer relationship, customer satisfaction Degree, customer loyalty, customer growth ratio, customer maintenance costs, supplier relationship, honor award

In the course of the study, the contents of the intellectual capital disclosure will be classified according to the criteria of Table 1, and then the information content will be analyzed. As the level of content disclosure does not have a statutory document to regulate the level of each vocabulary, we make adjustment based on the Firer and Williams (2002) specifications, and divided it into four levels, as shown in Table 2, 
Tab. 2 Scoring Rules of Single Disclosure Channel

\begin{tabular}{|c|c|c|c|c|}
\hline Score & $\begin{array}{l}\text { Without any } \\
\text { Disclosure } \\
\text { Information }\end{array}$ & $\begin{array}{l}\text { Include the } \\
\text { description of } \\
\text { intellectual } \\
\text { capital } \\
\text { information }\end{array}$ & $\begin{array}{l}\text { Include the } \\
\text { data of } \\
\text { intellectual } \\
\text { capital } \\
\text { informatio } \\
n\end{array}$ & $\begin{array}{c}\text { Both include } \\
\text { the } \\
\text { description } \\
\text { and the data } \\
\text { of intellectual } \\
\text { capital } \\
\text { information }\end{array}$ \\
\hline Company & & & & \\
\hline $\begin{array}{l}\text { Annual } \\
\text { Report }\end{array}$ & 0 & 1 & 2 & 3 \\
\hline $\begin{array}{l}\text { Official } \\
\text { website }\end{array}$ & 0 & 0.5 & 1 & 1.5 \\
\hline $\begin{array}{c}\text { Official } \\
\text { microbloggi } \\
\text { ng }\end{array}$ & 0 & 0.25 & 0.5 & 0.75 \\
\hline $\begin{array}{l}\text { Double } \\
\text { sources } \\
\text { (annual } \\
\text { report + } \\
\text { website) }\end{array}$ & 0 & 1.5 & 3 & 4.5 \\
\hline $\begin{array}{c}\text { Double } \\
\text { sources } \\
\text { (annual } \\
\text { report }+ \\
\text { microbloggi } \\
\text { ng) }\end{array}$ & 0 & 1.25 & 2.5 & 3.75 \\
\hline $\begin{array}{c}\text { Multi- } \\
\text { source(annu } \\
\text { al report }+ \\
\text { website }+ \\
\text { microbloggi } \\
\text { ng) }\end{array}$ & 0 & 1.75 & 3.5 & 5.25 \\
\hline
\end{tabular}

Taking into account intellectual capital information from the annual report, the official website and microblogging can play different role in investor's confidence, the score must be distinguished, the scoring rules of intellectual capital information disclosure through a variety of sources are as shown in Table 3.

Tab. 3 Scoring Rules of Multi-source Disclosure

\begin{tabular}{|c|c|c|c|c|}
\hline Score & $\begin{array}{l}\text { Without any } \\
\text { Disclosure } \\
\text { Information }\end{array}$ & $\begin{array}{c}\text { Include the } \\
\text { description of } \\
\text { intellectual capital } \\
\text { information }\end{array}$ & $\begin{array}{l}\text { Include the } \\
\text { data of } \\
\text { intellectual } \\
\text { capital } \\
\text { information }\end{array}$ & $\begin{array}{c}\text { Both } \\
\text { Include } \\
\text { the } \\
\text { descript } \\
\text { ion and } \\
\text { the data } \\
\text { of } \\
\text { intellect } \\
\text { ual } \\
\text { capital } \\
\text { informa } \\
\text { tion }\end{array}$ \\
\hline $\begin{array}{c}\text { Company } \\
\text { Annual } \\
\text { Report }\end{array}$ & 0 & 1 & 2 & 3 \\
\hline $\begin{array}{l}\text { Official } \\
\text { website }\end{array}$ & 0 & 0.5 & 1 & 1.5 \\
\hline $\begin{array}{c}\text { Official } \\
\text { microbloggin } \\
\mathrm{g}\end{array}$ & 0 & 0.25 & 0.5 & 0.75 \\
\hline
\end{tabular}

In order to achieve the comparison between the sample companies, the intellectual capital of the multi-source information disclosure is divided by the full score of the intellectual capital of multi-source information disclosure, then we can access to intellectual capital multi-source information disclosure index (ICDI), the formula is as follows

$$
I C D I_{i}=\sum_{i=1}^{40} X_{i} Y_{i} / 210
$$

Among them, ICIDI is the standard for the company's intellectual capital information disclosure index, $\mathrm{Xi}$ is the standard for the i-index which is disclosed in the annual report, Yi means the weight of the $\mathrm{i}$-index, in order to avoid the subjectivity which is induced when determining the weight as the classification of intellectual capital projects, $\mathrm{Yi}$ is the weight determined by the intellectual capital project classification, and it is set to 1 in the formula. In fact, the company's intellectual capital specific content is different, the disclosure preferences are different, and thus the company's disclosure of intellectual capital is equally important to their respective companies. In order to improve the objectivity and accuracy of the intellectual capital information, two members of our team has made the content analysis according to the same part of the annual report, we find that the results of the two sides are basically the same.

\section{(3) Intermediary variables: investor confidence}

Baker and Stein (2004) propose that measuring low investor confidence by using the liquidity indicators. While the most commonly indicators to measure the liquidity is the turnover of stock yearly. Turnover of stock yearly refers to the frequency of stock trading in the market during a certain period of time. According to the actual situation of China's market, you can go long, but cannot go short. It is a typical unilateral market. Only the process of rising stock prices can be profitable, investment activities of the investors will be active, so that the stock market is active.

Thus, the level of turnover is closely related to the degree of interest of investor on the stock, and is positively related to investor confidence. When the stock market continues to slump, the government will take the relevant control measures, investors will wait and see. In this circumstance, investors are lack of the confidence, the stock market is not active, and stock turnover remains at a low level. When the stock market continues to improve, the investor's investment confidence are improved. The stock market has obvious unilateral characteristics under the premise of the socialist market economy with Chinese characteristics, and the index of stock turnover can be better quantified to reflect investor confidence.

\section{(4) Control variable}

In order to ensure the reliability of the test, this paper refers to the previous research results, and selects the following indicators which may affect the corporate value and investor confidence as control variables. The variable description is shown in Table 4. 
Tab.4 Description of the Major Variable

\begin{tabular}{|c|c|c|c|}
\hline $\begin{array}{l}\text { Variabl } \\
\text { e Type }\end{array}$ & $\begin{array}{l}\text { Variable } \\
\text { Name }\end{array}$ & $\begin{array}{l}\text { Variable } \\
\text { Symbol }\end{array}$ & Description \\
\hline $\begin{array}{l}\text { Explain } \\
\text { Variabl } \\
\mathrm{e}\end{array}$ & $\begin{array}{l}\text { Corporate } \\
\text { value }\end{array}$ & TQ & Tobin Q Value \\
\hline $\begin{array}{l}\text { Explana } \\
\text { tory } \\
\text { variable } \\
\mathrm{s}\end{array}$ & $\begin{array}{l}\text { Intellectual } \\
\quad \text { Capital } \\
\text { Information } \\
\text { Disclosure } \\
\text { Index }\end{array}$ & ICDI & $\begin{array}{l}\text { Total Score of the Intelligence } \\
\text { Capital Information Disclosure } \\
\text { of the sample companies / Full } \\
\text { Value of the Intelligence } \\
\text { Capital Information Disclosure } \\
\text { of the Sample Companies }\end{array}$ \\
\hline $\begin{array}{l}\text { Median } \\
\text { variable }\end{array}$ & $\begin{array}{l}\text { investor } \\
\text { confidence }\end{array}$ & Ic & Turnover of the stock yearly \\
\hline \multirow{5}{*}{$\begin{array}{l}\text { Control } \\
\text { variable }\end{array}$} & profitability & Lev & $\begin{array}{c}\text { Return on net assets }=\text { net } \\
\text { profit } \div \text { equity at the end of the } \\
\text { period } \times 100 \% \\
\text { Asset-liability ratio }=\text { Total } \\
\text { liabilities } \div \text { Total assets } \times \\
100 \%\end{array}$ \\
\hline & Firm scale & Size & $\begin{array}{c}\text { The natural logarithm of the } \\
\text { book value }\end{array}$ \\
\hline & Growth & Growth & $\begin{array}{l}\text { Main business income growth } \\
\text { rate }=\text { (main business income } \\
\text { in this year - main business } \\
\text { income in the previous year) } \\
\div \text { main business income in the } \\
\text { previous year } \times 100 \%\end{array}$ \\
\hline & Net cash flow & Cash & $\begin{array}{l}\text { Net cash flow =net cash } \\
\text { flow from operating } \div \text { total } \\
\text { operating income }\end{array}$ \\
\hline & $\begin{array}{l}\text { Ownership } \\
\text { concentration }\end{array}$ & Con & $\begin{array}{l}\text { The sum proportion of } \\
\text { the top ten shareholders } \\
\text { holding }\end{array}$ \\
\hline $\begin{array}{l}\text { Dummy } \\
\text { variable }\end{array}$ & year & Year & dummy variable \\
\hline
\end{tabular}

\section{Regression model}

In order to test the relationship between intellectual capital information disclosure and corporate value and to know whether investor confidence is an intermediary variable, according to the variables and related influencing factors involved in the hypothesis, this paper draws on the method of testing the intermediary variables. As there is a certain lag of the market reaction, so this article using the previous period of intellectual capital information disclosure index. Intellectual capital information disclosure index of the actual data is from the year 2012 to 2015 . According to this article, the following three models are constructed:

$$
\begin{aligned}
& T Q=\alpha_{0}+\alpha_{1} I_{C D I} I_{t-1}+\alpha_{2} \text { Roe }+\alpha_{3} \text { Lev }+\alpha_{4} \text { Size } \\
& +\alpha_{5} \text { Growth }+\alpha_{6} \text { Cash }+\alpha_{7} \text { Con }+\sum Y E A R+\varepsilon \\
& \text { Ic }=\beta_{0}+\beta_{1} I C D I_{t-1}+\beta_{2} \text { Roe }+\beta_{3} \text { Lev }+\beta_{4} \text { Size } \\
& +\beta_{5} \text { Growth }+\beta_{6} \text { Cash }+\beta_{7} \text { Con }+\sum Y E A R+\varepsilon \\
& T Q=\gamma_{0}+\gamma_{1} I C D I_{t-1}+\gamma_{2} \text { Ic }+\gamma_{3} \text { Roe }+\gamma_{4} \text { Lev } \\
& +\gamma_{5} \text { Size }+\gamma_{6} \text { Growth }+\gamma_{7} \text { Cash }+\gamma_{8} \text { Con }+\sum Y E A R+\varepsilon
\end{aligned}
$$

The model (1) is used to test the correlation between the intellectual capital information disclosure index and the corporate value, and if $\alpha_{1}$ is positive, then $\mathrm{H} 1$ is valid. The model (2) is used to test the relationship between the multi- source intellectual capital information disclosure index and the investor's confidence, and if $\beta_{1}$ is positive, then $\mathrm{H} 2$ is valid. The model (3) is used to test that the investor's confidence plays a mediating role between the intellectual capital information disclosure index and the firm's value relationship. If $\alpha_{1}, \beta_{1}, \chi_{2}$ are positive, and $\chi_{1}<\alpha_{1}$,the intermediary effect exists, it assumes that model (3) is validated.

\section{EMPIRICAL RESULTS}

\section{A. Descriptive statistics}

The results in Table 5 show that the effect of extreme values on the results is removed by the treatment of the samples.

Tab.5 Descriptive statistics

\begin{tabular}{ccccc} 
Variable & Average & Standard deviation & Minimum & Maximum \\
$T Q$ & 4.5931 & 3.5547 & 0.6422 & 35.0824 \\
ICDI & 0.4044 & 0.1038 & 0.0733 & 0.608 \\
Ic & 196.3476 & 142.7464 & 0.1197 & 949.8514 \\
Roe & 0.0596 & 0.1162 & -1.8069 & 0.4500 \\
Lev & 0.2809 & 0.1606 & 0.0111 & 0.8864 \\
Size & 21.1248 & 0.6815 & 19.3995 & 23.8902 \\
Growth & 0.2956 & 0.5138 & -0.9106 & 5.8017 \\
Cash & 0.2276 & 0.1639 & & \\
& & & & \\
Con & 0.6012 & 0.1155 & 0.0044 & 0.8734 \\
& & & & \\
\hline
\end{tabular}

After removing the extreme value, the average of the sample company's corporate value is 4.5931, the standard deviation of 3.5547 . The difference between the maximum and the minimum of the corporate value is large, which indicates that there is a certain degree of difference in the corporate value of different enterprises. The average value of the multi-source intellectual capital information disclosure index is 0.4044 , the minimum value is 0.0733 and the maximum value is 0.608 , which indicates that the information disclosure status of the listed companies is different. Investor confidence in the minimum value is 0.1197 , the maximum value is 949.8514, indicating that the GEM company's investor confidence is uneven. The average return on net assets is $5.96 \%$, the average asset-liability ratio is $28.09 \%$, the average value of assets is 21.1248 , the main business growth rate is $29.56 \%$, the net cash flow is 0.2276 and the equity concentration is 0.6012 . 


\section{B. Correlation analysis}

STATA 14.0 provides a function about Pearson correlation analysis between two variables. This function was used to analyze correlation between independent variable and dependent variable. The table 6 is the results:

Tab.6 Pearson Correlations Coefficient Matrix for Variables

\begin{tabular}{|c|c|c|c|c|c|c|c|c|c|}
\hline & $T Q$ & $I C D I$ & Ic & Roe & Lev & Size & $\begin{array}{l}\text { Gro } \\
\text { wth }\end{array}$ & Cash & $\begin{array}{l}C \\
o\end{array}$ \\
\hline$T Q$ & $\begin{array}{r}1.00 \\
00\end{array}$ & & & & & & & & \\
\hline$I C$ & 0.17 & 1.00 & & & & & & & \\
\hline$D I$ & 46 & 00 & & & & & & & \\
\hline$I c$ & $\begin{array}{r}0.29 \\
24\end{array}$ & $\begin{array}{r}0.18 \\
81\end{array}$ & $\begin{array}{r}1.00 \\
00\end{array}$ & & & & & & \\
\hline Roe & $\begin{array}{r}0.11 \\
44\end{array}$ & $\begin{array}{r}0.03 \\
08\end{array}$ & $\begin{array}{r}- \\
0.03 \\
55\end{array}$ & $\begin{array}{r}1.00 \\
00\end{array}$ & & & & & \\
\hline Lev & $\begin{array}{r}- \\
0.17 \\
40\end{array}$ & $\begin{array}{r}- \\
0.05 \\
99\end{array}$ & $\begin{array}{r}0.00 \\
46\end{array}$ & $\begin{array}{r}- \\
0.14 \\
52\end{array}$ & $\begin{array}{r}1.00 \\
00\end{array}$ & & & & \\
\hline Size & $\begin{array}{r}- \\
0.07 \\
77\end{array}$ & $\begin{array}{r}- \\
0.14 \\
17\end{array}$ & $\begin{array}{r}- \\
0.01 \\
92\end{array}$ & $\begin{array}{r}0.11 \\
53\end{array}$ & $\begin{array}{r}0.42 \\
19\end{array}$ & $\begin{array}{r}1.00 \\
00\end{array}$ & & & \\
\hline $\begin{array}{l}\text { Gro } \\
\text { wth }\end{array}$ & $\begin{array}{r}0.15 \\
13\end{array}$ & $\begin{array}{r}0.02 \\
15\end{array}$ & $\begin{array}{r}0.01 \\
76\end{array}$ & $\begin{array}{r}0.12 \\
28\end{array}$ & $\begin{array}{r}0.22 \\
70\end{array}$ & $\begin{array}{r}0.25 \\
66\end{array}$ & $\begin{array}{r}1.00 \\
00\end{array}$ & & \\
\hline $\begin{array}{c}\text { Cas } \\
h\end{array}$ & $\begin{array}{r}0.07 \\
21\end{array}$ & $\begin{array}{r}0.08 \\
28\end{array}$ & $\begin{array}{r}0.04 \\
04\end{array}$ & $\begin{array}{r}0.10 \\
94\end{array}$ & $\begin{array}{r}0.51 \\
00\end{array}$ & $\begin{array}{r}0.24 \\
60\end{array}$ & $\begin{array}{r}0.12 \\
96\end{array}$ & $\begin{array}{r}1.00 \\
00\end{array}$ & \\
\hline Con & $\begin{array}{r}- \\
0.01 \\
24\end{array}$ & $\begin{array}{r}0.40 \\
64\end{array}$ & $\begin{array}{r}- \\
0.23 \\
97\end{array}$ & $\begin{array}{r}0.03 \\
18\end{array}$ & $\begin{array}{r}- \\
0.10 \\
06\end{array}$ & $\begin{array}{r}- \\
0.17 \\
17\end{array}$ & $\begin{array}{r}- \\
0.01 \\
23\end{array}$ & $\begin{array}{r}0.10 \\
45\end{array}$ & $\begin{array}{l}0 \\
0 \\
0 \\
0\end{array}$ \\
\hline
\end{tabular}
Correlation is significant at the 0.05 level (2-tailed); *: Correlation is significant at the 0.1 level (2-tailed).

Table 6 provides the Pearson correlation analysis between variables. From the correlation coefficient matrix of each variable, we can see that investor confidence, total return on assets, net cash flow is significantly positively correlated with the corporate value. The intellectual capital disclosure index is significantly positively correlated with the corporate value, and is positively correlated with investor confidence. These are consistent with our expectations. In addition, the VIF values are small. The average VIF is 1.4 , proving there will be no serious multi-colinearity between the variables with the introduction of these variables at the same time.

\section{Regression results and analysis}

Tab.7 Regression results and analysis

\begin{tabular}{|c|c|c|c|}
\hline Variable & TQ & Ic & TQ \\
\hline ICDI & 4.9884 & 440.1386 & 3.259929 \\
\hline & $\left(5.1^{* * *}\right)$ & $\left(10.35^{* * *}\right)$ & $\left(3.22^{* * *}\right)$ \\
\hline Ic & & & 0.0042 \\
\hline & & & $(6.03 * * *)$ \\
\hline Roe & 3.1754 & -9.4911 & 3.3041 \\
\hline & $(3.9 * * *)$ & $(-0.26)$ & $(4.09 * * *)$ \\
\hline Lev & -3.5007 & -11.7972 & -3.4977 \\
\hline & $(-4.86 * * *)$ & $(-0.37)$ & $(-4.96 * * *)$ \\
\hline Size & -0.9732 & -19.0041 & -0.8711 \\
\hline
\end{tabular}

\begin{tabular}{|c|c|c|c|} 
& $\left(-6.11^{* * *}\right)$ & $(-2.74 * * *)$ & $\left(-5.56^{* * *}\right)$ \\
\hline Growth & 1.2264 & 4.0774 & 1.2151 \\
\hline & $\left(6.6^{* * *}\right)$ & $(0.50)$ & $(6.67 * * *)$ \\
\hline Cash & 1.4037 & -9.3567 & 1.3672 \\
\hline & $(2.13 * *)$ & $(-0.33)$ & $\left(2.12^{* *}\right)$ \\
\hline Con & -0.5993 & -423.9556 & 1.0230 \\
\hline & $(-0.68)$ & $\left(-10.98^{* * *}\right)$ & $(1.11)$ \\
\hline Year & controlled & controlled & controlled \\
\hline Adjust R2 & 0.3141 & 0.1906 & 0.3354 \\
\hline \multicolumn{2}{|c|}{ Note: The parameters are estimated for the t test value; *,**, *** indicate } \\
significant levels of $10 \%, 5 \%$ and $1 \%$.
\end{tabular}

From the regression results of Table 7 , we can see that the regression index of multi-source intellectual capital information disclosure index is 4.9884 , and it is significant at $1 \%$ statistical level, indicating that after controlling other variables, there is a significantly positive correlation between the intellectual capital information disclosure index and the corporate value of the listed companies on the GEM, H1 is established. From the regression results of model (2), we can see that the regression index of intellectual capital information disclosure index is 440.1386, and the intellectual capital information disclosure index is positively correlated with investor confidence, and $\mathrm{H} 2$ is established. From the regression results of model (3), the regression coefficient of investor confidence is 0.0042 , and it is significant at $1 \%$ statistical level, which indicates that investors' confidence is positively correlated with the corporate value after controlling other variables. The regression coefficient of intellectual capital information disclosure index is 3.259929 , and the significance level is $1 \%$. Compared with the model (1), the coefficient and significance are small. It indicates that after the investor confidence is added to the model, the correlation of the intellectual capital information disclosure index with the value of technological firms is reduced. If $\alpha_{1}$ $\left.\left(\alpha_{1}=4.9884\right), \beta_{1}, \beta_{1}=440.1386\right), \chi_{2}\left(\chi_{2}=0.0042\right)$ are significant, and $\chi_{1}<\alpha_{1}$, it implies that the mediating effect exists. $\chi_{1}$ in the model (3) is also significant, indicating that the investor confidence play a part of the intermediary role in the relationship between the intellectual capital and corporate value. Finally, the intermediary effect of investor confidence is $35 \%$ of the total effect, which indicates the existence of the intermediary effect of investor confidence. On the other hand, it also shows that the intermediary effect belongs to some intermediary, and investor confidence can not completely replace intellectual capital information disclosure. It is only a possible role in the path of intellectual capital information disclosure impact on the corporate value, so H3 is established.

\section{Robustness test}

In order to verify whether the results of the previous study are robust or not, this paper will use the intellectual capital information disclosure evaluation index system and scoring method constructed by Zhang Dan (2008). The model is the 
same as the previous study. We get a similar empirical result, which shows that the empirical results are robustness.

In addition to this test, we also conducted a number of other robustness test, such as changing part of the control variables. We use the natural logarithm of sales revenue to measure company size and the like. These robustness tests do not change the previous test results.

\section{CONCLUSIONS}

This paper uses the multi-source information in big data environment to measure the disclosure of intellectual capital, and studies whether there is relationship among the intellectual capital information disclosure, investor confidence and the value of the enterprise. Through the theoretical and empirical analysis, this paper indicates that the level of intellectual capital information disclosure is higher, the value of corporate performance is better. Moreover, it shows that investor confidence plays a mediating role in the relationship between the intellectual capital information disclosure and the corporate value. The conclusion of this paper also has some enlightenments to the management and the government administration.

First, listed companies should broaden the sources of intellectual capital information disclosure to achieve the transparency of enterprise information. In the continuous development of big data environment, more and more enterprises have begun to use the official website and microblogging to disclose intellectual capital information. With the continuous development of information technology in the future, the company can disclose information through the official microblogging, the official WeChat platform, the official mobile app and other means.

Secondly, the listed companies should improve the quality of intellectual capital information to achieve the improvement of corporate value. Listed companies should attach great importance to the quality of intellectual capital information and improve the transparency of intellectual capital information. The disclosure of intellectual capital should be concrete and institutionalized, which can make investors obtain relevant information of enterprises more intuitively and enhance the corporate value.

Thirdly, the government should improve the relevant system of intellectual capital information disclosure. Strengthening the construction of capital market related system and promoting the effective disclosure of intellectual capital in multi - source are both necessary. Regulators should improve the credibility of intellectual capital information. And guide the healthy development of investor decision-making actively, which can promote enterprise to play the role in increasing corporate value and allocating resources effectively.

\section{References}

[1] Dumay, J. A critical reflection on the future of intellectual capital: from reporting to disclosure,Journal of Intellectual Capital,2016,11(7):168-184.

[2] Kaplan, A.M. and Haenlein, M. Users of the world, the challenges and opportunities of Social Media, Business horizons, 2010, 53(1): 59-68.

[3] Safko, L. and Brake, D.K. The Social Media Bible: Tactics, Tools, and Strategies for Business Success, 2009. Wiley, Hoboken, NJ.

[4] Dumay, J. and Guthrie, J. Involuntary disclosure of intellectual capital: is it relevant?.Journal of Intellectual Capital, 2017, 18(1): 30-45.

[5] Blankespoor, Elizabeth, Gregory S. Miller, and Hal D. The Role of Dissemination in Market Liquidity: Evidence from Firms' Use of Twittet. The Accounting Review, 2013, 89(1): 79-112.

[6] Sonnier G. P, McAlister L, RutzOJ. A Dynamic Model of the Effect of Online Communications on Firm Sale. Marketing Science.2011,30(4):702-716.

[7] Alessandra Lardo, John Dumay, Raffaele Trequattrini, Giuseppe Russo, Social media networks as drivers for intellectual capital disclosure: Evidence from professional football clubs. Journal of Intellectual Capital.2016,18(1):63-80.

[8] Mishari M. Alfraih. The value relevance of intellectual capital disclosure: empirical evidence from

[9] Kuwait. Journal of Financial Regulation and Compliance.2017,25(1):22-38.

[10] Abdolmohammadi M J. Intellectual capital disclosure and market capitalization. Journal of intellectual capital, 2005, 6(3): $397-416$.

[11] Vafaei A,Taylor D,Ahmed K.The value relevance of intellectual capital disclosures. Journal of Intellectual Capital. 2011, 12(3): 407-429.

[12] Orens R, AertsW, Lybaert N. Intellectual capital disclosure, cost of finance and firm value. Management Decision.2009,47(10):1536-1554.

[13] Beysekera, I. The influence of board size on intellectual capital disclosure by Kenyan listed firms, Journal of Intellectual Capital, 2011, 11(4):504-518.

[14] Miller, G.S. and Skinner, D.J. The Evolving Disclosure Landscape: How Changes in Technology, the Media, and Capital Markets are Affecting Disclosure. Journal of Accounting Research, 2015,53(2):221-239.

[15] Lee, L.F., Hutton, A.P. and Shu, S. The Role of Social Media in the Capital Market: Evidence from Consumer Product Recalls. Journal of Accounting Research, 2015, 53(2):367-404.

[16] Byck A., N. Volchkova, and L Zingalea The Coxporate Governance Role of the Media: Evidence from Russia[J].Journal of Finance,2008, 63(3):1093-1135.

[17] Dyck,A.,and L. Zingales.The Corporate Governance Role of the Media.No.W9309 [J] .National Bureau of Economic Research, 2002.83(1):1-28. 
[18] Botosan C A. Disclosure level and the cost of equity capital[J].Accounting review, 1997,23(6): 323-349.

[19] Bharath, J. Sunder and S. V, Sunder. Accounting Quality and Debt Contracting[J].The Accounting review, 2008.83(1):1-28.

[20] Bushee,B. J., J. E. Core, W. Guay, and Sophia J. W. Hamni The Role of the Business Press as an Information Intermediary [J].Journal of Accounting Research,2010, 11(4): 261-279.

[21] Chen K C W, Chen Z, Wei K C. Legal protection of investors, corporate governance, and the cost of equity capital[J].Journal of Corporate Finance, 2009, 15(3): 273-289.

[22] C.SAgnes

Cheng,Denton

Collins,Henry

$\mathrm{He}$
Huang.Shareholder rights, financial disclosure and the cost of equity capital[J],Review of Quantitative Finance and Accounting, 2006; 27(33):175-204.

[23] Dhaliwal D S,Li O Z,Tsang A,eta1.Voluntary Nonfinancial Disclosure and the Cost of Equity Capital:The Initiation of Corporate Social Responsibility Reporting[J].The Accounting Review,2011,86.

[24] Easley D, O'hara M. Information and the cost of capital[J].The journal of finance,2004,59(4): 1553-1583.

[25] El Ghoul S, Guedhami O, Kwok C C Y, et al. Does corporate social responsibility affect the cost of capital? [J].Journal of Banking\&Finance, 2011, 35(9): 2388-2406. 